\section{NIH panel opens debate on ethics of embryo research}

\begin{abstract}
Washington. An advisory panel convened by the US National Institutes of Health (NIH) to look at the moral and ethical issues raised by the use of human embryos in federally funded research got off to a slow but steady start last week.

The panel has been set up to help Harold Varmus, the director of NIH, to develop guidelines governing the review and conduct of such research. It has less than six months to prepare a report on its recommendations, which will be presented at the July meeting of the advisory committee to the director of NIH.
\end{abstract}

Last June, Congress lifted the de facto ban on the use of federal funds for human embryo research. Since then, NIH has received almost 40 grant proposals for support in this and the related area of parthenogenesis. Although the proposals fall outside the jurisdiction of current guidelines, all have received approval by local institutional review boards.

The 19-member panel consists of experts in basic and clinical research, ethics, law, social science, public health and public policy and is chaired by Steven Muller, president emeritus of Johns Hopkins University, in Baltimore, Maryland.

Varmus has asked the panel members to advise him on which areas of human embryo research are deemed acceptable, which warrant further review, and which are unacceptable. The highly controversial area of germline gene modification is not within the purview of this panel.

Before last June, research involving in search for the past 13 years or so. and embryo 'cloning' (twinning). vitro fertilization (IVF) had to be reviewed by an ethics advisory board (EAB). In a report issued in 1979, the board found it ethically acceptable for the federal government to support or conduct research involving human IVF and embryo transfer. But the dissolution of the board in 1980 has effectively blocked federal funding of such re-

Despite the regulatory blockade, research - most of which has been directed towards improving the outcome of IVF — has been undertaken in the private sector. But Jonathan Van Blerkom, of the department of molecular, cellular and developmental biology at the University of Colorado, said that much of it has not been "meaningful", claiming that many studies were poorly designed.

Varmus told the panel that although the EAB report was timely in 1979 , "the passage of 15 years, and a number of scientific and social changes, limit its applicability".

Charles McCarthy, former staff director of the EAB and now a member of the board of Public Responsibility in Medicine and Research, said that seeing the issues finally under discussion was "a dream come true".

Over the next six months, the panel will address a number of controversial issues surrounding human embryo research, such as whether it is permissible to create embryos solely for research purposes rather than use 'spare' embryos created during IVF, the use of fetal ovaries as a potential source of ova with which to create embryos,

Diane Gershon

\section{Japan sets up gene therapy panel}

Tokyo. Japan's Ministry of Health and Welfare announced on Monday ( 7 February) the members of a committee that will screen all proposals for investigating the clinical applications of gene therapy, opening the way for research in this field in Japan.

But the Ministry of Education, Science and Culture has yet to make clear what regulatory system it will establish for screening such research in universities.

The 17-member committee is made up of specialists from a broad range of fields. They include: Kenichi Matsubara, head of Japan's human genome project; Masaki Terada, director of the National Cancer Centre Research Institute; Ayako Sono, a wellknown novelist and Suzuo Matsuda, a former journalist with Jiji wire service.

All applications for experiments involving gene transfer in humans will be examined by the committee, including those to be carried out in universities, after initial screening by an internal committee within the relevant institution.

The new committee will therefore function in a similar fashion to the Recombinant DNA Advisory Committee of the US National Institutes of Health. But, unlike the US committee, it is not expected to open its deliberations to the press and public; government committees in Japan usually carry out their deliberations behind closed doors.

The education ministry has yet to clarify its own position, and has in fact been approaching members of the ministry of health committee, asking for their help in establishing a separate screening system for the universities they oversee. But this is causing confusion among university researchers who are uncertain about where they must go to obtain approval for proposed experiments.

David Swinbanks

\section{France seeks views on improvements in research system}

Paris. Sixty thousand copies of a report on the issues facing French science were distributed to laboratories last week as the government launched its national consultation on research. The exercise has been planned as a run-up to a debate in the National Assembly in June which the government plans to use to launch a new national strategy for research.

The report sets the agenda for six regional meetings being held over the coming weeks in Marseilles, Grenoble, Bordeaux, Strasbourg, Le Mans and Lille. But it will disappoint those impatient for new ideas. Its main content is a long list of deficiencies of the research system, many already wellknown. Members of the committee that drafted the report in consultation with scientific and industrial organizations and trade unions say they avoided specific recommendations in order to leave the debate open.

"Lack of time" is blamed for the report's admission that it is not exhaustive. But it omits nuclear research, despite its large share of the civil budget - ostensibly because the National Assembly will discuss this as part of a debate on energy.

Similarly, the report omits any consideration of defence research, even though the government seems increasingly committed to pursuing an integrated approach to civilian and military research (see Nature 367, 102; 1994).

Many of the deficiencies described in the report result from what François Fillon, the minister for higher education and research, has called the "worrying rigidity" of the French system. In particular, it criticizes the fact that salaries and overheads lock up most of the budgets of the research organizations, leaving them little money for research.

The report also suggests that France should revise the goals of its costly grands programmes technologiques in aeronautics, space, nuclear science and computing. In particular, says the report, France should "state clearly" whether it needs a manned space programme or a new generation of nuclear reactors.

More than 1,800 scientists and industrialists are expected to attend the planned regional meetings, and a further 1,500 a national summing-up in Paris on 9 April. Edouard Balladur, the prime minister, will take part in some of the meetings.

The government has also established a special electronic bulletin board, postbox and fax line to let other researchers make their views known. But whether it intends to heed what is said - or simply, as some fear, to use the consultation to claim a mandate for a fait accompli - remains to be seen.

Declan Butler 